\title{
Cardiovascularis betegségek megítélése a gépjármúvezetői engedélyek kiadásának vagy meghosszabbításának szempontjából az európai uniós jogharmonizációt követően
}

\author{
Végh Ernő dr. - Kiss Balázs dr. - Dézsi Csaba András dr. \\ Petz Aladár Megyei Oktató Kórház, Kardiológiai Osztály, Győr
}

\begin{abstract}
Az Európai Unió (EU) által elő́írt jogharmonizációs kötelezettségekkel összhangban valamennyi tagországnak ugyanazon elveknek megfelelően és azonos értékelési rendszer szerint kell megítélnie a vezetőii engedélyek egészségügyi elbírálását. A 2016/1006. számú EU-direktíva alapján valamennyi tagországnak legkésőbb 2018 januárjától alkalmaznia kell az egységes egészségügyi elbírálást a jármúvezetői engedélyek elbírálásakor, így ez hazánkban is életbe lépett 2018. január 12-én. A hazai aktuális törvényi szabályozás legfontosabb forrásdokumentuma a 2013-ban közzétett szakértői konszenzusdokumentum, a „New Standards for Driving and Cardiovascular Diseases”. Ez a jármúvezetést befolyásoló cardiovascularis betegségeknek a szakértói értékelése, melynek fontosságát az is adja, hogy az érvényben lévő magyar törvényrendelet is erre hivatkozik. Összefoglalónkban az aktuális törvényeknek megfelelően, a napi munkát segítő gyakorlati útmutatót adunk a gyakori cardiovascularis kórképek jármúvezetői engedélyre vonatkozó megítéléséhez.
\end{abstract}

Orv Hetil. 2019; 160(10): 370-377.

Kulcsszavak: gépjármúvezetői engedély, cardiovascularis betegségek, eszméletvesztés, szívelégtelenség, pacemaker

\section{Evaluation of cardiovascular diseases in connection with the issuing or renewal of driving licenses following the European Union law harmonization}

The European Union (EU) law harmonization expects from each EU country to apply the same principles and same standards of the medical evaluation of driving licenses. All EU member states have to apply common evaluations of the driving licenses - based on the EU Regulation 2016/1006 - at the latest from January of this year. Hungary launched this new regulation on the 12th of January 2018. The most important source document of the current national regulation is the expert consensus document "New Standards for Driving and Cardiovascular Diseases" published in 2013. This is the professional evaulation of the cardiovascular diseases which can influence driving, and its importance is highlighted because even the Hungarian law listed this document as a resource. In this summary, in accordance with the current law, we provide a practical guide for the day-to-day work of assessing the permission of driving licence in connection with the different kinds of cardiovascular diseases.

Keywords: driving license, cardiovascular diseases, syncope, heart failure, pacemaker

Végh E, Kiss B, Dézsi CsA. [Evaluation of cardiovascular diseases in connection with the issuing or renewal of driving licenses following the European Union law harmonization]. Orv Hetil. 2019; 160(10): 370-377.

(Beérkezett: 2018. szeptember 16.; elfogadva: 2018. október 24.) 


\section{Rövidítések}

$\mathrm{ACI}=$ arteria carotis interna; $\mathrm{ACS}=$ akut coronariaszindróma; alk. = alkalmassági; ÁPM = állandó pacemaker; AS = aortastenosis; $\mathrm{AV}=$ atrioventricularis; $\mathrm{AVA}=$ (aortic valve area $)$ aortabillentyü-area; AVNRT = atrioventricularis nodalis reentry tachycardia; AVRT = atrioventricularis reentry tachycardia; BTSZB = bal-Tawara-szár-blokk; CABG $=$ (coronary artery bypass grafting) koszorúérbypass-mútét; $\mathrm{CMP}=$ cardiomyopathia; $\mathrm{EF}=$ ejekciós frakció; EMMI = Emberi Erőforrások Minisztériuma; EPS = (electrophysiology study) elektrofiziológiai vizsgálat; $\mathrm{EU}=$ Európai Unió; $\mathrm{HCM}$ = hypertrophiás cardiomyopathia; ICD = (implantable cardioverter-defibrillator $)$ implantálható cardioverter defibrillátor; ISZB = ischaemiás szívbetegség; JTSZB = jobb-Tawara-szár-blokk; mitr. insuff. = a mitralis billentyú elégtelensége; NM = Népjóléti Minisztérium; NSTEMI = nem ST-elevációval járó myocardialis infarctus; nsVT = (non-sustained ventricular tachycardia) nem tartós kamrai tachycardia; NYHA $=($ New York Heart Association $)$ New York-i Szívbetegséggel Foglalkozó Társaság; PCI = perkután coronariaintervenció; $\mathrm{PF}$ = pitvarfibrilláció; $\mathrm{SA}=$ sinoauricularis; $\mathrm{SCAD}=($ stable coronary artery disease $)$ stabil arteria coronaria betegség; SES = supraventricularis extrasystole; SSS = $($ sick sinus syndrome $)$ sinuscsomó-betegség; std. = stádium; STEMI = ST-elevációval járó myocardialis infarctus; sVT = (sustained tachycardia) tartós kamrai tachycardia; TdP VT = (torsade de pointes ventricular tachycardia) 'torsade de pointes' kamrai tachycardia; TIA $=$ (transiens ischemic attack) átmeneti ischaemiás roham; VES = ventricularis extrasystole; WPW-sy = Wolff-Parkinson-White-szindróma

Hatályba lépett 2018. január 12-én az Emberi Erőforrások Minisztériumának (EMMI) 1/2018. (I. 12.) rendelete „A közúti jármúvezetők egészségi alkalmasságának megállapításáról szóló 13/1992. (VI. 26.) NM-rendelet módosításáról" [1], mely számos gyakorlati kérdést vet fel a praktizáló orvosok napi munkája során. A rendelet melléklete egyértelmúen megfogalmazza, mely betegségek milyen stádiumában kell végleg eltiltani a jármúvezetéstől a beteget, azonban nem tér ki a napi rutin során gyakran alkalmazandó átmeneti korlátozások részleteire.

A hatályos rendelet a vezetői engedélyekről szóló 2006/126/EK európai parlamenti és tanácsi irányelv [2] módosításáról szóló, 2016. július 7-i EU 2016/1106os bizottsági irányelvnek [3] való megfelelést szolgálja, melynek legfontosabb forrásdokumentuma a 2013-ban közzétett szakértői konszenzusdokumentum, a „New Standards for Driving and Cardiovascular Diseases" [4]. Ez utóbbi szakmai anyag dolgozza fel részletesen a gépjármúvezetést befolyásoló cardiovascularis kórképeket, és jelentőségét az adja, hogy erre hivatkozik a hazai jogszabály is.

Ebben az összefoglalóban a hatályos törvényi rendeleteknek megfelelően, a szakértői ajánlást [4] alapul véve megkísérelünk praktikusan használható útmutatást adni a gépjármúvezetői engedély kiadhatóságának vagy korlátozásának megítéléséről a gyakoribb cardiovascularis kórképek tekintetében.

\section{Törvényi háttér}

A jármúvezetői engedélyek kiadását és meghosszabbítását 2018-ig a 13/1992. (VI. 26.) NM rendelet „A közúti jármúvezetők egészségi alkalmasságának megállapításáról" szabályozta [5]. Ez egy 26 éves rendelet, azóta a kardiológiában számos új diagnosztikus és terápiás lehetőség, újonnan definiált kórkép jelent meg.

Az Európai Unióhoz való csatlakozásunk után a jogharmonizáció miatt az EU közösségi iránymutatásai szerint kell múködnünk. Az EU-ban a gépjármúvezetés egészségügyi megítélését folyamatosan napirenden tartották, mely kezdődött a 2006/126/EK direktívával, majd a 2009-es és 2014-es irányelv-módosítások következtek, végül a jelentős változást a 2016. június 7-i (EU) 2016/1106-os bizottsági irányelv hozta el [2, 3]. A 2016-os EU-irányelv cardiovascularis szempontból legfontosabb szakmai alapját a 2013-as szakértői konszenzusajánlás jelentette [4], mely valamennyi érintett európai ország szakértőinek bevonásával készült; összeállításakor hazánkat a szakbizottságban dr. Karlóczai Kristóf képviselte.

A 2016-os EU-irányelv valamennyi európai ország számára kötelezővé tette 2018-tól a jármúvezetői engedély elbírálásának egységes szabályozását, így lépett hatályba hazánkban az 1/2018. (I. 12.) EMMI rendelet „A közúti jármúvezetők egészségi alkalmasságának megállapításáról szóló 13/1992. (VI. 26.) NM rendelet módosításáról”. A rendelet mellékleteiben a jármúvezetőknek a neurológiai, pszichiátriai, diabetológiai és cardiovascularis szempontok szerinti értékelése van feltüntetve.

\section{A jármúvezetéssel kapcsolatos definíciók}

A jármúvezetőket a törvény két nagy csoportba sorolja, az l. alkalmassági csoportba (köznapi nevén „úrvezeto””) és a 2. alkalmassági csoportba (köznapi nevén „hivatásos vezeto"”).

A törvény az alábbiak szerint rendelkezik a kategóriákról:

Az 1. alkalmassági csoportba kell sorolni azt a közúti jármúvezetőt, aki a közúti közlekedési igazgatási feladatokról, a közúti közlekedési okmányok kiadásáról és viszszavonásáról szóló 326/2011. (XII. 28.) kormányrendelet (KR) 2. melléklete szerinti „Al” kategóriába, „A2” kategóriába, „A” korlátozott kategóriába, „A” kategóriába, „Bl” kategóriába, „B” kategóriába, „BE” kategóriába tartozó jármúvet vezet vagy kíván vezetni.

A 2. alkalmassági csoportba kell sorolni azt a közúti jármúvezetôt, aki

a) a KR 2. melléklete szerinti „Cl”, „ClE”, „C", „CE”, „Dl”, „DlE”, „D”, „DE” kombinált vagy „TR” trolibuszi kategóriába tartozó jármúvet vezet vagy kíván vezetni,

b) a közúti közlekedési szolgáltatás keretében közúti járművet, megkülönböztető jelzéssel ellátott közúti jár- 
múvet vezet vagy kíván vezetni, valamint akit közúti jármúvezetői munkakörben foglalkoztatnak, függetlenül a vezetni kívánt jármű kategóriájától.

A fentiek alapján például a taxisofór és a mentősofơr is a hivatásos jogosítvány, vagyis a 2 . alkalmassági (alk.) csoport irányelvei szerint bírálandó el.

Az egészségi alkalmasságot arra a csoportra vonatkozóan kell megállapítani, amelyre azt az orvosi vizsgálaton megjelent személy kérte. Az 1. alk. csoportra vonatkozóan alkalmasnak minősített személy nem folytathat olyan jármüvezetői tevékenységet, amelyhez a 2. alk. csoport szerinti egészségi alkalmasság megállapítása szükséges. A 2. alk. csoportba sorolt személyt, egészségi alkalmasságának megállapítása esetén, alkalmasnak kell tekinteni az l. alk. csoport tekintetében is.

\section{Meddig adbató ki/hosszabbitható a jogositvány?}

Az 1. alkalmassági csoportba tartozó közúti jármúvezetők közül az, aki

a) az 50. életévét még nem töltötte be, 10 évre

b) az 50. életévét betöltötte, de a 60 . életévét még nem töltötte be,

c) a 60. életévét betöltötte, de a 70. életévét még nem töltötte be,

d) a 70. életévét betöltötte, 5 évre

kaphat jogosítványt.

A 2. alkalmassági csoportba tartozó közúti jármúvezetők közül az, aki

a) a 60. életévét nem töltötte be,

b) a 60. életévét betöltötte,

5 évre; kaphat jogosítványt.

Az egészségi alkalmasság megállapítását végző egészségügyi szerv az időszakos egészségi alkalmassági vizsgálatra a fent meghatározott időnél rövidebb határidőt is megállapíthat, ha a közúti jármúvezető-jelölt vagy a közúti jármúvezető egészségi állapota azt indokolja.

\section{Végleges egészségi alkalmatlanság kardiológiai kórképekben}

Az érvényes jogszabály melléklete pontosan definiálja, hogy mely kardiológiai betegségekben tilos vezetni.

Az 1. alkalmassági csoport esetén egészségi alkalmatlanságot kell megállapítani a következő szív- és érrendszeri betegségek fennállása esetén:

a) perifériás vascularis megbetegedések - mellkasi és hasi aortaaneurysma, ha az aorta legnagyobb átmérője alapján ruptura veszélye áll fenn (>55 mm), és így a vezetési alkalmasságot befolyásoló hirtelen esemény bekövetkezésének jelentős a kockázata;

b) szívelégtelenség: NYHA IV. stádium (std.);

c) szívbillentyűzavar aorta-visszaáramlással, aortaszűkülettel, mitralis visszaáramlással vagy mitralis szúkülettel, ha a funkcionális képesség a becslés szerint NYHA IV. std.-nak felel meg, vagy ha voltak ájulásos epizódok; d) Brugada-szindróma ájulással vagy túlélt hirtelen szívhalállal.

A 2. alkalmassági csoport esetén egészségi alkalmatlanságot kell megállapítani a következő szív- és érrendszeri betegségek fennállása esetén:

I. Valamennyi egészségügyi ok, mely a jelöltet alkalmatlanná teszi az l. alk. csoport esetében.

II. A csak a 2. alk. csoportra érvényes korlátozások:

a) defibrillátori funkcióval rendelkező pacemaker (ICD) beültetése után;

b) szívelégtelenség:

- NYHA III. és IV. std.,

- NYHA I. és II. std. esetén sem vezethet, ha a bal kamra ejekciós frakciója $(\mathrm{EF})<35 \%$;

c) szívmúködést segítő eszközök;

d) a szívbillentyú-betegségek alábbi típusai:

- bármely billentyúbetegség NYHA III. vagy IV. std.ban,

- bármely billentyúbetegség 35\% alatti ejekciós frakcióval,

- mitralis szúkület pulmonalis hypertoniával,

- echokardiográfiával igazolt súlyos aortastenosis, kivéve azt a tünetmentes aortastenosist, melynél a fizikai tûrőképességet vizsgáló teszt követelményei teljesülnek,

- aortastenosis + ájulásos rosszullét;

e) a hypertrophiás cardiomyopathia (HCM) alább felsorolt esetei:

- HCM + anamnézisben ájulás,

- HCM + a következő problémák közül kettő vagy több fennáll:

- 3 cm-t meghaladó bal kamrai falvastagság,

- paroxismalis kamrai aritmia,

- hirtelen halál a családi kórelőzményben (elsőfokú rokonok esetén),

- a vérnyomás nem emelkedik fizikai terhelés során.

\section{Mely kórképekben szükséges kardiológiai szakorvosi vélemény?}

A következő szív- és érrendszeri betegségek fennállása esetén az egészségi alkalmasságot csak szakorvosi vélemény ismeretében és akkor lehet megállapítani, ha a kérelmező betegségét eredményesen kezelték. Az alább listázott betegségek csoportosítása, sorrendje és a csoportok betűjele megegyezik a jogszabályban felsoroltakkal.

a) Alacsony pulzusszámmal járó szívritmuszavarok (sinuscsomó-betegség és ingerületvezetési zavarok) és magas pulzusszámmal járó szívritmuszavarok (supraventricularis és ventricularis szívritmuszavarok) a szívritmuszavarból adódó ájulással vagy ájulásos epizódokkal a kórelőzményben;

b) magas pulzusszámmal járó szívritmuszavarok (supraventricularis és ventricularis szívritmuszavarok), ha 
strukturális szívbetegséggel és elhúzódó ventricularis tachycardiával (VT) társulnak;

c) tünettel járó angina pectoris;

d) defibrillátor beültetése vagy cseréje, illetve megfelelő vagy nem megfelelő defibrillátorsokk;

e) ájulás (gyors kialakulás, rövid időtartam és spontán felépülés által jellemzett átmeneti eszmélet- és izomtónusvesztés globális agyi hipoperfúzió következtében, vélhetőleg reflexátvitelü, ismeretlen okú, szívbetegségre utaló bizonyíték nélkül);

f) akut szívkoszorúér-szindrómára utaló tünetek;

g) stabil angina pectoris;

b) perkután szívkoszorúér-beavatkozás;

i) szívkoszorúérbypass-mútét;

j) vérzéses vagy ischaemiás stroke/traumás intracerebralis vérzés/tranziens ischaemiás roham, TIA;

k) jelentős (noninvazív vizsgálattal 70-99\% közötti) nyakiverőér-szűkület vagy okklúzió;

l) az aorta maximális átmérője meghaladja az 5,5 cm-t; m) NYHA I., II., III. std. (szívelégtelenség mértéke); n) szívátültetés;

o) szívmúködést segítő eszközök használata;

p) szívbillentyưmútét;

q) malignus magas vérnyomás (a systolés vérnyomás legalább $180 \mathrm{Hgmm}$ vagy a diastolés vérnyomás legalább $110 \mathrm{Hgmm}$, fenyegető vagy progresszív szervkárosodással);

r) veleszületett szívbetegség;

s) hypertrophiás cardiomyopathia, ha nem társul hozzá ájulás;

t) hosszú QT-szindróma ájulás, 'torsade de pointes' vagy 500 ms-t meghaladó QTc kíséretében.

Az egyes kórképek részletes, a konszenzusdokumentum ajánlásai alapján való tárgyalásakor el kell térni a törvény általi sorrendtől, hogy az összetartozó kórképek (például ritmuszavarok, coronariabetegségek) logikus, összetartozó sorrendben legyenek megtalálhatók. Az alábbi kórképek értékelésénél a jogszabály úgy rendelkezik, hogy amíg az állapot nem alakult ki, nem adható ki a szakvélemény. Ez konkrét példán bemutatva azt jelenti, hogy például egy diagnosztizált II. fokú AV blokkos, állandó pacemaker (ÁPM) beültetésére váró beteg a végleges definitív terápia elvégzéséig (ÁPM-beültetés) ideiglenesen nem vezethet. Erre a kezelőorvosának írásban dokumentáltan fel kell hívnia a beteg figyelmét. A pacemaker beültetését követően kell majd a vezetési alkalmasságát véglegesen elbírálni.

\section{Bradycardiák (lásd a rendelet a. pontját)}

\section{Sinusbradycardia}

Nincs limitáció sem az 1-es, sem a 2-es csoportra. Ha azonban szédüléssel vagy syncopéval jár, akkor ezek kivizsgálásáig - melybe indokolt esetben az elektrofiziológiai vizsgálat (EPS) is beletartozik - nem vezethet.
„SSS” (sinus arrest/SA-blokk/tachy-brady szindróma/ chronotrop inkompetencia)

1-es csoport:

- Ha az anamnézisben syncope van, akkor csak eredményes, definitív kezelés után vezethet.

2-es csoport:

- Ha az anamnézisben syncope vagy hirtelen elgyengülés van, akkor csak eredményes kezelés után vezethet, ha szakorvos ezt megítéli.

$A V$-blokkok (II. fokú AV-blokk, III. fokú AV-blokk, magas fokú $A V$-blokkok)

1-es csoport:

- Ha az anamnézisben syncope vagy hirtelen elgyengülés szerepel, akkor csak ÁPM-rel, vagy amennyiben annak hátterében reverzibilis ok állt, annak megszüntetése után vezethet.

2-es csoport:

- Ha az anamnézisben syncope vagy hirtelen elgyengülés van, akkor csak ÁPM-rel vagy a reverzibilis ok megszüntetése után vezethet.

Bi-és trifascicularis blokkok

l-es csoport:

- Ha nem volt syncope, akkor vezethet.

- Syncope esetén csak ÁPM beültetése után vezethet.

2-es csoport:

- Syncope esetén csak ÁPM beültetése után vezethet.

- Alternáló bal-Tawara-szár-blokk (BTSZB) és jobbTawara-szár-blokk (JTSZB) esetén syncope nélkül is ÁPM kell.

\section{Congenitalis AV-blokk}

1-es csoport:

- Ha az anamnézisben syncope vagy szignifikáns releváns tünetek vannak, akkor csak ÁPM beültetése után vezethet.

2-es csoport:

- Tünetmentes beteg is csak ÁPM beültetése után vezethet.

\section{Tachycardiák (lásd a rendelet a. pontját)}

Pitvarfibrilláció (PF)/pitvari flattern/pitvari tachycardia 1-es csoport:

- Ha nincs syncope az anamnézisben, akkor vezethet.

- Syncope esetén csak akkor vezethet, ha a ritmuszavar kezelt és kontrollált.

2-es csoport:

- Ha nincs syncope az anamnézisben, és a CHADSVASc2 score szerint antikoagulált, akkor vezethet.

- Syncope esetén csak akkor vezethet, ha a ritmuszavar kezelt és kontrollált, vagyis tachycardia esetén frekvenciakontroll bevezetése szükséges, és ha a ritmuszavar jelentkezése mellett a syncope nem ismétlődött, akkor kardiológiai vizsgálat után kiadható/hosszabbítható a jogosítvány. 
Supraventricularis tachycardiák ( $A V N R T, A V R T$, preexcitáció/WPW-szindróma)

l-es csoport:

- Ha az anamnézisben nincs syncope, akkor vezethet.

- Ha van syncope, akkor csak a ritmuszavar hatékony kezelése után vezethet.

2-es csoport:

- Ha az anamnézisben nincs syncope vagy szédüléssel járó palpitáció, akkor vezethet.

- Ha az anamnézisben tünetek vannak, akkor csak megfelelő terápia (ablatio, gyógyszeres kezelés) után vezethet, ha a rekurrencia veszélye kicsi.

- Preexcitáció esetén csak aritmológus specialista véleménye után vezethet.

\section{Kamrai ritmuszavar ép szív esetén} (lásd a rendelet a. pontját)

VES-aritmia/nsVT ép szín esetén

1-es csoport:

- VES és tünetmentes nsVT esetén vezethet.

2-es csoport:

- VES-aritmia esetén vezethet.

- Tünetmentes monomorf nsVT esetén vezethet.

- Tünetes monomorf nsVT esetén nem vezethet.

- Polimorf nsVT esetén még tünet nélküli esetben sem vezethet.

A fenti limitáló esetekben csak kezelés után, kardiológiai vélemény után vezethet. Amennyiben ICD kell, lásd az ICD szabályozását.

Tartós kamrai tachycardia (sVT) ép szív esetén

1-es csoport:

- Ha az anamnézisben korlátozó tünet van, akkor nem vezethet.

- Csak megfelelő kezelés és kardiológiai vélemény után vezethet.

2-es csoport.

- Ha az anamnézisben korlátozó tünet van, nem vezethet.

- Csak megfelelő kezelés és kardiológiai vélemény után vezethet újra.

- Ha ICD kell, lásd az ICD szabályozását.

\section{Kamrai ritmuszavar beteg szipen}

(lásd a rendelet b. pontját)

\section{VES-aritmia/nsVT beteg sziven}

1. csoport:

- VES és tünetmentes nsVT esetén vezethet.

- Ha szívelégtelenség, ischaemiás szívbetegség (ISZB) korlátozza, akkor azon szabályok szerinti elbírálás szükséges.

2. csoport:

- Tünetmentes VES-aritmia esetén vezethet, ha nincs más limitáció.
- Tünetmentes monomorf nsVT esetén vezethet, ha nincs más limitáció.

- Tünetes monomorf nsVT esetén nem vezethet.

- Polimorf nsVT esetén egyedi elbírálás, kardiológiai szakvélemény kell.

- Ha ICD kell, lásd annak szabályozását.

Tartós kamrai tachycardia (sVT) beteg sziven

1. csoport:

- Nem vezethet, amíg a sVT nincs kontrollálva.

- A szív egyéb betegségeinek (ISZB, NYHA-std., ICD) elbírálása tovább limitálhat.

2. csoport:

- Nem vezethet addig, amíg a sVT megszúnése minimum 3 hónapon át nincs kontrollálva és dokumentálva.

- Értékelni kell a szív egyéb lehetséges betegségeit is, például ISZB, NYHA-std., ICD, cardiomyopathia (CMP).

\section{ICD-s betegek (lásd a rendelet d. pontját)}

A 2. csoport esetén az ICD kizáró ok!

Az ICD-vel kapcsolatban az alábbiak az 1. csoportra vonatkoznak:

ICD-beültetés szekunder prevenciós indikációban: 3 hónap múlva vezethet.

ICD-beültetés primer prevenciós indikációban: 2 hét múlva vezethet.

ICD adekvátan üt: az eseményt követően 3 hónapig nem vezethet.

ICD inadekvátan üt: tilos vezetni addig, amíg ismételt ellenőrzésekkel az inadekvát sokkleadás biztonsággal elkerülhető lesz.

\section{Syncope (lásd a rendelet e. pontját)}

Ez határterület, lásd a törvény neurológiai szempontú rendelkezéseit is [1].

Syncope kizárólag a súlyos sérülések kapcsán, fokozott vagustónussal: nincs korlátozás.

Syncope kizárólag orvosi beavatkozások kapcsán (akár rekurrens is): nincs korlátozás.

1. Ismétlődő reflexsyncope vasovagalis vagy reflexeredettel:

- 1. csoport: 6 hónapos tünetmentesség után vezethet;

- 2. csoport: nem adható ki, nem hosszabbítható a jogosítvány.

2. Ismétlődő vagy súlyos syncope köhögés vagy nyelés miatt:

- 1. csoport: 6 hónapos tünetmentesség után vezethet;

- 2. csoport: nem adható ki, nem hosszabbítható a jogosítvány. 


\section{Arteria carotis interna szükület}

(lásd a rendelet k. pontját)

1. csoportú vezetői engedély és arteria carotis interna (ACI) stenosis:

- nincs korlátozás;

- ha TIA vagy stroke van, akkor a neurológiai korlátozások lépnek életbe [1].

2. csoportú vezetői engedély és ACI-stenosis:

- súlyos ACI-stenosis esetén csak a funkcionális kardiológiai teszt eredménye függvényében vezethet;

- ha TIA vagy stroke van, akkor a neurológiai korlátozások lépnek életbe [1].

\section{Akut coronariaszindróma (ACS) (lásd a rendelet $f$. pontját)}

1. csoportú vezetői engedély és ACS:

- ha a beteg tünetmentessé vált, akkor vezethet (instabil angina);

- ha myocardiumsérülés történt (STEMI, NSTEMI), akkor 4 hét múlva vezethet.

2. csoportú vezetői engedély és ACS:

- 6 hét múlva vezethet, ha addig tünetmentes, és a funkcionális teszt negatív (kardiológiai szakvélemény kell).

\section{Stabil angina pectoris (SCAD) \\ (lásd a rendelet g. pontját)}

1. csoportú vezetôi engedély és SCAD:

- nem vezethet, ha nyugalmi angina is van, vagy ha vezetés közben is vagy kis fizikai megterhelés mellett is angina pectoris jelentkezik;

- akkor vezethet, ha bizonyítottan kis fizikai terhelésre már nem lép fel angina.

2. csoportú vezetői engedély és SCAD:

- tünetes SCAD-beteg nem kaphat hivatásos jogosítványt! Csak akkor vezethet, ha a kezelés hatására angina pectoris nem jelentkezik, és ezt funkcionális teszttel igazoljuk.

\section{Koszorúer katéteres tágitása (PCI) (lásd a rendelet h. pontját)}

Az akut PCI esetén az ACS ajánlásai érvényesek!

1. csoportú vezetői engedély és elektív PCI:

- ha a beteget jó klinikai állapotban emittáljuk, akkor vezethet.

2. csoportú vezetői engedély és elektív PCI:

- a beteg 4 hét múlva vezethet, ha klinikailag tünetmentes, és a funkcionális teszt megfelelő (kardiológiai szakvélemény szükséges).
Koszoruérbypass-mütét (CABG)

(lásd a rendelet i. pontját)

1. csoportú vezetői engedély és elektív CABG:

- megfelelő sebgyógyulás és jó klinikai állapot elérésekor vezethet.

2. csoportú vezetôi engedély és elektív CABG:

- megfelelő sebgyógyulás és jó klinikai állapot elérésekor, ha a funkcionális teszt negatív, vezethet.

\section{Mellkasi és hasi aortaaneurysma (lásd a rendelet l. pontját)}

1. csoportú vezetői engedély és aortaaneurysma:

- ha az aorta ascendens/hasi aorta átmérője $>55 \mathrm{~mm}$, akkor nem vezethet;

- Marfan-szindróma esetén már kisebb méretek is korlátozóak!

2. csoportú vezetői engedély és aortaaneurysma:

- ha bármelyik aortaszakasz átmérője >55 mm, akkor nem vezethet!

- Marfan-szindróma esetén már kisebb méretek is korlátozóak!

\section{Szivelégtelenség (lásd a rendelet $m$. pontját)}

1. csoportú vezetői engedély és szívelégtelenség:

- NYHA I., II., III. esetén vezethet;

- NYHA IV. esetén nem vezethet.

2. csoportú vezetői engedély és szívelégtelenség:

- NYHA I., II. esetén vezethet, ha az EF>35\%;

- NYHA III., IV. esetén nem vezethet.

\section{Szintranszplantáció (lásd a rendelet $n$. pontját)}

1. csoportú vezetői engedély és szívtranszplantáció:

- nincs korlátozás.

2. csoportú vezetői engedély és szívtranszplantáció:

- egyedi mérlegelés szükséges, kardiológiai szakvélemény kell.

\section{Cardiac assist device („müszíp”) (lásd a rendelet 0 . pontját)}

1. csoportú vezetői engedély és „müszív”:

- egyedi mérlegelés, kardiológiai vélemény a gondozóintézetből.

2. csoportú vezetôi engedély és „műszív”:

- nem vezethet.

\section{A szíbillentyük betegségei (lásd a rendelet p. pontját)}

1. csoportú vezetői engedély és aortabillentyü-elégtelenség:

- NYHA I., II., III. std. esetén vezethet; 
- NYHA IV. std. esetén nem vezethet.

2. csoportú vezetői engedély és aortabillentyü-elégtelenség:

- NYHA I., II. std. esetén vezethet;

- NYHA III., IV. std. esetén nem vezethet.

Aortastenosis (AS)

1. csoportú vezetői engedély és aortastenosis:

- NYHA I., II., III. std. esetén vezethet;

- syncope és/vagy NYHA IV. std. esetén nem vezethet.

2. csoportú vezetői engedély és aortastenosis:

- NYHA I., II. std. esetén vezethet;

- NYHA III. IV. std. esetén nem vezethet;

- súlyos AS (echó: 80/40 Hgmm gradiens, AVA [aortabillentyú-area] $<1 \mathrm{~cm}^{2}$ ) esetén nem vezethet;

- AS + syncope esetén nem vezethet.

A mitralis billentyű elégtelensége

1. csoportú vezetői engedély és mitralis regurgitatio:

- NYHA I., II., III. std. esetén vezethet;

- NYHA IV. std. esetén nem vezethet.

2. csoportú vezetői engedély és mitralis regurgitatio:

- NYHA I., II. std. esetén vezethet;

- NYHA III., IV. std. esetén nem vezethet;

- ha az $\mathrm{EF}<35 \%$, akkor nem vezethet.

A mitralis billentyú szúkülete

1. csoportú vezetôi engedély és mitralis stenosis:

- NYHA I., II., III. std. esetén vezethet;

- syncope és/vagy NYHA IV. std. esetén nem vezethet.

2. csoportú vezetői engedély és mitralis stenosis:

- NYHA I., II. std. esetén vezethet;

- NYHA III., IV. std. esetén nem vezethet;

- súlyos pulmonalis hypertonia és/vagy syncope esetén nem vezethet.

\section{Szípbillentyümütét (lásd a rendelet p. pontját)}

1. csoportú vezetői engedély és szívbillentyưmuutét utáni állapot:

- megfelelő sebgyógyulás és megfelelő orális antikoaguláns (OAC-) kezelés esetén már vezethet;

- szívelégtelenség esetén az ottani szabályozás érvényes (NYHA I., II., III. std. esetén vezethet).

2. csoportú vezetői engedély és szívbillentyümütét utáni állapot:

- megfelelő sebgyógyulás és megfelelő OAC-kezelés esetén már vezethet;

- szívelégtelenség esetén az ottani szabályozás a mérvadó (NYHA I., II. std. esetén vezethet).

\section{Hypertonia (lásd a rendelet q. pontját)}

Terápiarezisztens, malignus hypertonia

1. csoportú vezetői engedély és malignus hypertonia:

- nem vezethet, míg nincs stabil vérnyomáskontroll.

2. csoportú vezetői engedély és malignus hypertonia:

- nem vezethet, míg nincs stabil vérnyomáskontroll.
Grade III. hypertonia (vérnyomás >180 systolés [syst.] és/vagy >110 diastolés [diast.] érték)

1. csoportú vezetői engedély és III. std.-ú hypertonia:

- vezethet - megfelelő vérnyomáskontroll esetén.

2. csoportú vezetői engedély és III. std.-ú hypertonia:

- Nem vezethet, míg nincs a vérnyomása stabilan beállítva.

Grade I. és II. hypertonia (vérnyomás < 180 syst. és/ vagy $<110$ diast.)

1. csoportú vezetői engedély és I. és II. std.-ú hypertonia:

- vezethet.

2. csoportú vezetői engedély és I. és II. std.-ú hypertonia: - vezethet.

\section{Hypertrophiás cardiomyopathia (HCM) (lásd a rendelet s. pontját)}

1. csoportú vezetői engedély és HCM:

- ha nincs syncope, akkor vezethet;

- ha volt syncope, akkor addig nem vezethet, amíg ennek az oka nem szünt meg, vagy nincs eredményesen kezelve.

2. csoportú vezetői engedély és HCM:

- ha nem volt syncope, akkor vezethet;

- nem vezethet, ha két feltételnél több megvan az alábbiakból:

1. bal kamrai falvastagság $>\mathbf{3 0} \mathrm{mm}$,

2. nsVT az anamnézisben,

3. a családi kórtörténetben hirtelen szívhalál szerepel,

4. fizikai aktivitás közben hirtelen vérnyomásesés alakul ki.

\section{Hosszú QT-szindróma (lásd a rendelet t. pontját)}

Ha az anamnézisben nincs 'torsade de pointes' kamrai tachycardia (TdP VT) és syncope, és a QT-szakasz az EKG-n nem volt hosszabb, mint 500 milliszekundum (ms), akkor nincs korlátozás még a 2. csoportban sem. Ha viszont az anamnézisben volt Tdp és/vagy syncope, vagy a QT>500 ms, akkor az alábbi korlátozások érvényesek.

1. csoportú vezetői engedély és hosszú QT-szindróma tünetekkel, vagy a QT-távolság >500 ms:

- nem vezethet, csak ha az adekvát terápiát megkapta, és aritmológus véleményezi a rizikóját.

2. csoportú vezetői engedély és hosszú QT-szindróma tünetekkel, vagy a QT-szakasz >500 ms:

- nem vezethet.

\section{Brugada-szindróma}

Ha az anamnézisben nincs syncope vagy abortált szívhalál, akkor nincs korlátozás még a 2. csoportban sem. Ha az anamnézisben volt syncope vagy abortált szívhalál, valamint felmerül az ICD indikációja, akkor az alábbi korlátozások érvényesek. 
1. csoportú vezetői engedély és Brugada-szindróma pozitív anamnézissel:

- csak ICD-beültetés után vezethet, az ICD-beültetésre vonatkozó szabályok szerint.

2. csoportú vezetői engedély és Brugada-szindróma pozitív anamnézissel:

- nem vezethet!

\section{Egyéb szinizombetegségek és a jogositvány megitélése (lásd a rendelet 4.1.3. pontját)}

A rendelet - preventív és előretekintő szemlélete alapján - a ritka és a tudomány mai állása szerint nem pontosan definiált kardiológiai betegségekről is említést tesz.

Az alábbi ismert szívizombetegségek, mint az arrhythmogen jobb kamrai CMP, a 'non-compact' CMP, a katecholaminerg CMP, a „rövid QT-szindróma”, valamint a még nem definiált szívizombetegségek esetén a jármüvezetői alkalmasság megítélése egyedi szakorvosi mérlegelést igényel. Itt annak megítélése szükséges, hogy milyen valószínüséggel léphet fel syncope vagy váratlan rosszullét, szívritmuszavar.

A fent részletezett számos kardiológiai betegség nyilvánvalóan nem ölelhette fel a teljes spektrumot, előfordulhatnak az ajánlásban nem részletezett klinikai állapotok. Ezekben az esetekben egyéni mérlegelés szükséges annak megítélésére, hogy a betegség okozhat-e eszméletvesztést, hirtelen elgyengülést, hirtelen súlyos állapotromlást, hirtelen szívhalált.

\section{Gyakorlati teendők a szakmai elbírálás után}

A gépjárművezetői alkalmasságot véleményező családorvos vagy szakorvos büntetőjogi felelősséggel is tartozik véleményéért, így amennyiben nem megfelelően értékelt megbetegedés következtében történik közlekedési baleset, nemcsak az előidézőt, hanem az alkalmasságot véleményező orvost is felelősségre lehet vonni.

Ha a beteget felszólítjuk, hogy korlátozó egészségi állapota miatt ne vezessen, arra számíthatunk, hogy ennek végrehajtására a betegek együttmúködési készsége alacsony [4]. A felmérések szerint a betegek az egészségügyi eredetú korlátozások közül az életminőségüket leginkább károsan érintőnek a jogosítvány bevonását tekintik [4].

Amennyiben járművezetési korlátozás szükséges, erről a törvény szerint [5] valamennyi orvosnak kötelessége értesíteni az elsőfokú hatóságot - a jelen jogértelmezés szerint a háziorvost -, aki megteszi a kötelező lépéseket a jogosítvánnyal kapcsolatban.

Az egészségügyben jártas jogi szakértők véleménye alapján a kardiológiai rutin számára az alábbi teendők megfontolása javasolt.

1. Ha bármilyen, a járművezetést korlátozó állapot felmerül a vizsgálat/kezelés alapján, azt közölni kell a beteggel, és a beteg dokumentációjában ezt fel kell tüntetni:

- a zárójelentésen fel kell tüntetni a korlátozás tényét és az ideiglenes korlátozás kezdetét és várható időtartamát, annak feloldási feltételeit;

- a zárójelentés egy példányát a beteggel alá kell íratni, és azt meg kell őrizni;

- ha a beteg ambulánslappal távozik, akkor abból még egy példányt ki kell nyomtatni, melyen rajta van a korlátozás leírása, és ezt a beteg által aláírt példányt archiválni kell.

2. A defenzív jogi megközelítés az, hogy a zárójelentés/ ambulánslap egy példányát nemcsak a betegnek adjuk, hanem postai úton, zárt borítékban direkt elküldjük háziorvosának is.

A cikk a szerzők véleményét tükrözi, a hatályos jogszabály alkalmazásának lehetséges módjához ad támpontot.

Anyagi támogatás: A közlemény megírása anyagi támogatásban nem részesült.

Szerzôi munkamegosztás: A szerzők egyenlő mértékben járultak hozzá a cikk elkészítéséhez, és a végleges változatát valamennyi szerző elolvasta és jóváhagyta.

Érdekeltségek: A szerzőknek nincsenek érdekeltségeik.

\section{Irodalom}

[1] Decree No. 1/2018 (I. 12.) of the Ministry of Human Capacities on modification of Decree No. 13/1992 (VI. 26.) of the Ministry of Health about the medical evaluation of public road drivers. [1/2018. (I. 12.) EMMI rendelet a közúti jármúvezetők egészségi alkalmasságának megállapításáról szóló 13/1992. (VI. 26.) NM rendelet módosításáról.] Hatályos jogszabályok gyüjteménye, Wolters Kluwer, Budapest. Available from: https://net.jogtar.hu [Hungarian]

[2] The implementation of Directive 2006/126/EC on driving licences - Annex report. Publications Office of the European Union, Luxembourg, November 2017. doi: 10.2832/720376.

[3] Directive 2016/1106/EU. Communication from the Commission to the European Parliament, the Council, the European Economic and Social Committee and the Committee of the Regions - Policy achievements in $2006 /{ }^{*}$ COM/2007/0067 final */.

[4] New Standards for Driving and Cardiovascular Diseases. Report of the Expert Group on Driving and Cardiovascular Disease. Publications Office of the European Union, Brussels, October 2013 Available from: https://ec.europa.eu/transport/road_ safety/sites/roadsafety/files/pdf/behavior/driving_and_cardiovascular disease final.pdf

[5] Decree No. 13/1992 (VI. 26.) of the Ministry of Health on medical evaluation of driving licenses of public road drivers. [13/1992. (VI. 26.) NM rendelet a közúti jármúvezetők egészségi alkalmasságának megállapításáról.] Hatályos jogszabályok gyưjteménye, Wolters Kluwer, Budapest. Available from: https:// net.jogtar.hu [Hungarian]

(Dézsi Csaba András dr., Györ, Vasvári Pál út 2-4., 9024 e-mail: dcsa62@gmail.com)

A cikk a Creative Commons Attribution 4.0 International License (https://creativecommons.org/licenses/by/4.0/) feltételei szerint publikált Open Access közlemény, melynek szellemében a cikk bármilyen médiumban szabadon felhasználható, megosztható és újraközölhető, feltéve, hogy az eredeti szerző és a közlés helye, illetve a CC License linkje és az esetlegesen végrehajtott módosítások feltüntetésre kerülnek. (SID_1) 